\title{
Agro-processing as a tool for poverty alleviation strategy: A case of Raymond Mhlaba municipality
}

\begin{tabular}{|c|c|}
\hline \multicolumn{2}{|c|}{$\begin{array}{l}\text { Authors: } \\
\text { Thandeka Khowa } 10 \\
\text { Tafadzwa J. Mukasi }{ }^{2} \text { (1) }\end{array}$} \\
\hline \multicolumn{2}{|c|}{$\begin{array}{l}\text { Affiliations: } \\
{ }^{1} \text { Department of Sociology } \\
\text { and Human Settlements, } \\
\text { Faculty of Social Sciences, } \\
\text { University of Fort Hare, Alice, } \\
\text { South Africa }\end{array}$} \\
\hline \multicolumn{2}{|c|}{$\begin{array}{l}{ }^{2} \text { Department of Development } \\
\text { Studies, Faculty of } \\
\text { Management and Commerce, } \\
\text { University of Fort Hare, Alice, } \\
\text { South Africa }\end{array}$} \\
\hline \multicolumn{2}{|c|}{$\begin{array}{l}\text { Corresponding author: } \\
\text { Thandeka Khowa, } \\
\text { tkhowa@ufh.ac.za }\end{array}$} \\
\hline \multicolumn{2}{|c|}{$\begin{array}{l}\text { Dates: } \\
\text { Received: } 12 \text { June } 2020 \\
\text { Accepted: } 23 \text { Apr. } 2021 \\
\text { Published: } 25 \text { Oct. } 2021\end{array}$} \\
\hline \multicolumn{2}{|c|}{$\begin{array}{l}\text { How to cite this article: } \\
\text { Khowa, T. \& Mukasi, T.J., } \\
\text { 2021, 'Agro-processing as a } \\
\text { tool for poverty alleviation } \\
\text { strategy: A case of Raymond } \\
\text { Mhlaba municipality', Africa's } \\
\text { Public Service Delivery and } \\
\text { Performance Review 9(1), } \\
\text { a463. https://doi. } \\
\text { org/10.4102/apsdpr.v9i1.463 }\end{array}$} \\
\hline \multicolumn{2}{|c|}{$\begin{array}{l}\text { Copyright: } \\
\text { (c) 2021. The Authors } \\
\text { Licensee: AOSIS. This } \\
\text { is licensed under the } \\
\text { Creative Commons } \\
\text { Attribution License. }\end{array}$} \\
\hline \multicolumn{2}{|l|}{ Read online: } \\
\hline 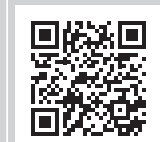 & $\begin{array}{l}\text { Scan this QR } \\
\text { code with your } \\
\text { smart phone or } \\
\text { mobile device } \\
\text { to read online. }\end{array}$ \\
\hline
\end{tabular}

Background: Agro-processing is viewed as a possible poverty alleviation tool for rural development in South African communities. Agro-processing can be a tool for income generation and local economic development for rural settings.

Aim: To examine the role and impact of cottage farming in Raymond Mhlaba municipality, rural Eastern Cape province. The study sought to identify ways of developing the cottage and agro-processing industries as a tool for poverty alleviation and local economic development.

Setting: Grounded on the sustainable development theory and the human capital development approach, the study explores how rural people in Raymond Mhlaba Municipality utilise their livelihood capitals as a tool for survival.

Method: The researcher employed a qualitative approach by using in-depth interviews and focus group discussion.

Results: The study revealed that rural households embark on various survival strategies, cottage farming being dominant.

Conclusion: The purpose of the study was to enhance small-scale farming using agroprocessing as a poverty alleviation strategy, thus promoting a sustainable rural development for the Eastern Cape province.

Keywords: cottage farming; agro-processing; rural development; poverty alleviation; Raymond Mhlaba Municipality local economic development.

\section{Introduction}

The development of a cottage farming is important for economic growth and the promotion of more pluralist societies. Cottage farming such as stock, crop and fish can be used as a tool for poverty alleviation, especially for rural communities. As labour-intensive activities, cottage industries play an important role in employing the growing workforce in rural communities and alleviating the severe unemployment that threatens the survival of the poor around the world. Ellis (1999) and Huttunen (2019) state that farming remains an important aspect for rural communal lives. South Africa faces numerous economic and social challenges - mainly high unemployment rate, high poverty rate and inequality. Agriculture is identified as a sector with the potential to contribute towards the amelioration of unemployment and high poverty rates. The subset of manufacturing that processes raw material and intermediate products derived from agriculture is a significant contributor towards rural development. It thus means using a set of technological and economic activities undertaken on basic agricultural resources with the aim of transforming them into usable items or products such as juice, etc. Small-scale farming is the common denominator amongst rural communities with the indigenous farming skills passed through generations, thus contributing towards agro-processing and sustainable rural development. Consequently, the government together with private stakeholders can usher rural development using agro-processing as a tool to commercialise small-scale farming (Kapur 2019).

Agriculture provides employment for the low-skilled and unskilled people. According to Pawlak and Kołodziejczak (2020), agriculture sector has a great potential to enable the desperately poor to survive, alleviate poverty, create employment and contribute to economic growth. The agricultural sector is an engine for growth and development in rural communities. Degu (2019) states that there is a linkage which exists amongst agriculture, the secondary and tertiary sector, 
with agriculture supplying these sectors with raw materials and in turn providing a market for generating goods and services.

According to Buheji and Ahmed (2019), who pioneered the concept revitalisation of rural areas, a process that seeks to reverse rural decline, to develop a more resilient, sustainable and diversified local economy and to enhance the quality of rural communities are essential for rural areas. Buheji and Ahmed (2019) further argued that the focus should be on creation and stimulation of opportunities that will generate income/jobs whilst preserving and enhancing the unique dynamics and features of livelihoods. Thus ensure stability and increase local rural population, by retaining and attracting young people, diversifying the economic and employment base, maintaining an acceptable participation and community pride and preserving and building on special rural attraction in the rural areas. In South Africa, a total of $35.7 \%$ of the population is regarded as rural and $64.3 \%$ as urban. The majority of the rural population lives in poverty, mainly the old and the young, as the youth migrates to urban areas with hopes of a better life and to seek employment (UN 2014).

Raymond Mhlaba local municipality is the second largest local municipality in the Eastern Cape, covering $6357 \mathrm{~km}^{2}$ and constituting $18 \%$ of the surface area of the Amatole District Municipality. It has an estimated population of 156000 with 41900 households with a total of $91.3 \%$ black people, $6.2 \%$ coloured people, $2.0 \%$ white people and $0.4 \%$ Asian people (Statistics South Africa [Stats SA] 2016). In this municipality, about $72 \%$ of the population resides in villages, $20 \%$ resides on farms and scattered settlements and 19\% resides in urban settlements, mostly Alice and Fort Beaufort, where the main concentration of businesses occurs (Socio-economic review and outlook 2017). The gender ratio indicates that approximately $40 \%$ of the total population is male, whereas approximately $60 \%$ is female.

Although there are some areas where men are dominant, a significant portion of the Raymond Mhlaba local municipal area is dominated by women (Socio-economic review and outlook 2017).

The official records reveal that the Raymond Mhlaba municipal economy is currently able to create jobs for only $3.5 \%$ of the economically active population. The income levels of the people of the Raymond Mhlaba municipal area are extremely low with 6531 people earning between R 401 and R 800 whilst $74 \%$ of the people do not have an income at all (The Nkonkobe Municipality 2016). The large number of unemployed people, mainly the young and women, calls for a greater need to look at innovative ways of creating employment and alleviating poverty. Raymond Mhlaba is a rural municipality and its local economy is largely driven by the agricultural sector, which includes citrus cultivation, forestry and crop production. The citrus industry is one of the municipality's largest employers. Forest plantations and timber processing are also undertaken in the area. Raymond Mhlaba local municipality is well known for its rich heritage and culture. The historic educational institutions of Healdtown, Lovedale College and the University of Fort Hare are important heritage sites in Raymond Mhlaba but as yet are underutilised as tourism or cultural sites. The tourism sector in a municipality with iconic natural resources in the form of the Amathole Mountains and nationally significant heritage sites remains largely unsupported and under exploited. Some of the major challenges facing Raymond Mhlaba local municipality include infrastructure challenges and high levels of unemployment and poverty. As agriculture is the dominant practice in the municipality, there is a need to enhance and adopt innovative ways to transform and revitalise this sector, thus creating employment and enhancing rural development of the Raymond Mhlaba local municipality.

Kat Citrus development projects are examples of the rural development strategies and innovation into agriculture. Kat Citrus is one of the developing agro-processing farm in the Alice area. Projects like these and the Mqanduli Maize Enterprise are good examples of what other municipalities can work towards in ensuring rural development. The government-funded Mqanduli rural enterprise development hub, which is in its third year, is projected to generate millions of rands for roughly 300 farmers who run it (Business Link 2019; Iortyom, Sonwabo \& Nel 2018). Furthermore, this has created employment for a lot of rural people and in the process ushered development for the rural Mqanduli villages.

According to Meyer (2014), the local government should play a vital role in rural development and job creation through infrastructure development, policy formulation, integration, support for small enterprise, creation of positive economic climate, facilitation of projects, formulation of strategies and provision of information.

Hermann (2009:5) points out that the main challenges impeding growth in rural settings are poor access to socioeconomic facilities, public services, infrastructure and other essential services. Rural areas face many challenges, and this calls for appropriate rural development policies and an efficient use of financial resources (OECD 2006:2). Siddiqui (2015) and Modrego and Cazzuffi (2015) in their studies list characteristics of rural communities which includes economically stagnated, agriculturally underdeveloped, lacking employment opportunities and where people live a poor quality of life because of lack of quality services and poor health condition. To eradicate poverty, a number of researchers share the same opinion that local economic development (LED) is imperative (Rogerson 2009:9). Local economic development has become a global concept that is generally aimed at addressing poverty and creating jobs in rural localities. This is because the greatest potential for development exists at the local government level. Local economic development mandate is to attract investments, create jobs and boost local economy (Meyer 2014).

The main question therefore is, if agriculture is of paramount importance and if we believe that it is the main tool for 
poverty alleviation in rural areas, why does poverty remains prevalent in rural areas? Programmes such as LED have been put in place aiming to address poverty, especially in disadvantaged communities. Policies are developed, which look good on paper; however, very little action is visible. It is against this background that this article examines agroprocessing and cottage farming as tools for rural development. The research objectives of this study were formulated as follows:

- to identify agro-processing as tools for poverty alleviation and diversify the community's livelihood activities to increase income in Raymond Mnhlaba Municipality

- to investigate on government funding for the development of rural cottage and small-scale farming in Raymond Mhlaba municipality.

\section{Theoretical framework}

This study is guided by the sustainable livelihood framework, which seeks to analyse survival livelihood strategies (Department of International Development 1999). The framework argues that rural society has assets that they use as means for survival. At the heart of the sustainable livelihood framework is the asset pentagon. These are human capital, social capital, natural capital, financial capital and physical capital: human capital - the skills, knowledge, ability to labour and good health; social capital - the social resources (networks, social claims, social relations, affiliations, association) upon which people draw when pursuing different livelihood strategies; natural capital - the natural resources stock (soil, water, air, genetic resources) and environmental services. These resources are useful for sustaining livelihoods. Financial capital includes cash, credit, savings schemes and other economic assets which is essential for the purist of a livelihood and physical capital includes infrastructure that are essential for the maintenance of livelihoods.

Sustainable livelihood framework conceptualises livelihoods in a holistic way, which captures the many constrains and opportunities they are subjected to. Livelihoods are shaped by numerous factors, ranging from global-level or national-level structures over which individuals have no control over assets that households have such as crops. Land cannot be used as a strategy to counteract such threats. Sustainable Livelihood Framewok (SLA) helps to reveal the possible contributions of agro-processing and cottage farming to poverty alleviation and livelihood development. The framework can be a valuable tool for a better understanding of agro-processing and cottage farming as an instrument for poverty alleviation in rural communities. Yunus (1998), as cited in Karnani (2017) and Walelign et al. (2017), argues that the primary causes of poverty are not lack of human capabilities or lack of demand for labour. He states that lack of demand for labour is only a symptom, not a cause of the poverty.

Inadequate understanding of human capabilities and failure to create enabling policies to support these capabilities cause poverty. Yunus' argument is that poverty is a result of economic, political and social processes that interact with each other and frequently reinforce each other in ways that exacerbate the deprivation in which poor people live (World Bank 2001). In this study, SLA helps to understand the complications of poverty and establish standards that assist to address and defeat poverty. Poverty is viewed as a major cause and effect of global environmental problem (Rein 1996). Rein (1996) states that 'Development does not start with goods, it starts with people and education, organisation and discipline'. He states that without these four all resources remain untapped.

\section{Methodology Research design}

The study followed a qualitative research method and employed in-depth interviews and focus group discussion. In-depth interviews allowed for a deeper scrutiny into the roles and impact of cottage industries in the Raymond Mhlaba municipality (Creswell 2013). It allows the researcher the first-hand/primary information with regard to the challenges experienced by cottage farmers/industries. Focus group discussions allowed participants to interact with other cottage farmers and share ideas and strategies. In the process of the discussions, the researcher gained insightful information from the participants as they shared their strategies, challenges and hopes for their small farming industries. Following the data collection process, the data were coded by means of selective and open coding, and themes were then identified (Babbie 2010).

\section{Sample and sampling}

The study utilised non-probability sampling by using the purposive sampling technique that sought to enhance representation, replication and generalisation. According to De Vos et al. (2012), purposive sampling refers to deliberately selecting the sample based on certain criteria, based entirely on the judgement of the researcher, in that a sample is composed of elements that contain the most characteristic, representative or typical attributes of the population' (De Vos et al. 2012). The sample size for this study consisted of two focus group of five participants each and 15 (in-depth interviews) cottage farmers from Raymond Mhlaba Municipality. The sample was selected by means of convenience sampling, and the researcher sought participants, who have small cottage farms, individuals or groups of business partners and any other participants who fit the criteria.

\section{Validity and reliability}

Validity and reliability were of paramount importance in conducting the study. Validity is said to be a matter of trustworthiness, utility and dependability of research finding. The research had a structured interview guide for in-depth interviews. The researchers used probing skills, thus ensuring prolonged engagement allowing for the 
saturation of the discussion. The research used audit trial of the verbatim transcriptions and themes (Krefting 1991).

\section{Ethical considerations}

Babbie and Mouton (2001:520) described ethics as associated with morality and dealing with matters of right and wrong. Given that the study includes human subjects and perceptions, the researcher observed the rights, needs, morals and wishes of the participants throughout the study (De Vos 1998). Respondents interviewed on a willing-toparticipate basis; confidentiality and anonymity were observed. In maintaining anonymity, the researcher used pseudonyms to identify the participants. The study abided by the ethical rules of the University of Fort Hare.

\section{Results}

The analysis resulted in the development of key themes that are diverse and small communal farming in, finance, marketing, gender and LED in Raymond Mhlaba as a survival strategy, thus leading to rural development.

\section{Small communal cottage farming}

Smallholder communal farming taking place in the Raymond Mhlaba varies from citrus (oranges), crops (maize, potatoes) to cattle farming (sheep, cows, goats). The majority of the respondents were crop farmers, that is, they used subsistence farming a means for food security for their families. Crop farming is further viewed by Raymond Mhlaba community members, as being the more flexible and cheaper to maintain. Village people use their small businesses as a source of income for their family. When the products are ripe, women in the village go to the neighbouring towns where they sell their products on the streets; this is evident in the town of Alice and Fort Beaufort. This raises the issue of gender, which will be tackled in the following section:

'We plant maize, so when it is ready as the women we join forces and go to town to sell our maize, we sell it ripe and we also have that is cooked. Whatever we make a day we come back together and share it. We have been doing this for years, on weekends our children also help which makes it better because we have more hands and make more money.' (Participant 5, Focus Group Discussion 2, 45 year old female, 2020)

However, there is very few agro-processing taking place in the Raymond Mhlaba community as much as a lot of people do farming, and very few understand agro-processing. According to participants the process of boiling, roasting and making soup from the maize and sell it to community individuals is viewed as a form of agro-processing; by so doing, they gain smaller amount of financial capital. When farming is carried out at a subsistence level, most of community members' farms are just to be able to feed their families. However, many of them would like a joint venture into agro-processing with the large-scale farmers and other stakeholders as they believe it would bring a lot of revenue and development in their village, creating employment in the process. Participants have seen and heard of agro-processing co-operation taking place in the Eastern Cape, mainly the Mqanduli maize co-operation:

'I have heard about the Mqanduli maize co-operation and have wished that one day government could come to our villages and also assist us, you know we farm maize and other vegetable here but no-one cares about us. We need help with our small farms also.' (Participant 3, In-depth-interview, 60 year old male, 2020)

\section{Finance}

The Kat Citrus development co-operation is one of the agro-processing projects, which is doing well in the Raymond Mhlaba municipality. The project is funded by industrial development zone (IDZ). Participants share the notion that getting funds is very hard for their rural projects as they still need a lot of training on formulating business plan, training on farming and on business skills. Small cottage farmers stress that it is not easy to get funding. Education level becomes a challenge as most of the farmers have primary level of education, and they are old and based in a rural area, which make it hard for them to access facilities in town. A lot of paper work is required to avail the facilities provided by banks and other government departments, which therefore is a challenge to uneducated people or people with little education as they find it hard to understand the processes and formalities needed to access the funding. The Kat Citrus development project is doing a lot of work in assisting other farmers who are in citrus farming by linking new farmers with the government's funding departments or organisations such as IDZ, Department of Trade and Industry (DTI), Department of Forestry and Fisheries (DFF), et cetera. One must highlight that this should not be a task for the Kat project but a task for the government to go to these rural areas and target agro-cottage industries or small farms that need assistance.

Furthermore, the government can conduct workshops and trainings in order to capacitate small-scale farmers with knowledge of funding processes, marketing strategies and monitoring, implementation and evaluation of relevant projects. Local economic development practitioners should also join forces in ensuring growth and development of rural communities:

'There is one man who has been trying to help our citrus farm, he helped us apply for funding from IDZ and we are still waiting for feedback. He has been teaching us better ways and methods we can use to improve productivity. With the funds we are looking at agro-processing of oranges into juice which we can sell to the market and creating employment.' (Participant 3, Focus Group Discussion 2, 38 year old male, 2020)

\section{Marketing problems}

Cottage industries mainly exist in villages where there are challenges of lack of transport, bad roads and poor communication facilities. These challenges handicap the producers from finding suitable markets for their products. Villages are situated at a distance from towns, making it hard 
for the cottage and small-scale farmers to access their target market from their local rural town:

'The village am in they come and buy from me ... my vegetables but sometimes I give them on credit because they are hungry and need something to cook ... they pay me month end when they have received their pension or grant money ... however some don't pay and there is nothing I can do.' (Participant 5, In-depth interview, 62 year old female, 2020)

'Alice is a small rural poor town ... you cannot market here.' (Participant 2, Focus Group Discussion 1, 60 year old male, 2020)

\section{Training}

From the responses, one can observe that small farms are mostly run by small groups having less or no training on management, organisation and day-to-day running of a business. Thus, it makes it hard for the small-scale farming to grow and to compete with other large-scale industries managed and organised by the specialists of that field. This calls for much effort to be taken by farmers with business knowledge in assisting small farmers to develop in aspects such as policy formulation, which are aimed directly at educating rural small farmers.

\section{Gender and age}

The issue of gender and age was raised by participants. The results have shown there are a large number of small, agrocommunity, farm co-operatives for women in the Raymond Mhlaba community, and women have joined together to farm crops, which they use as strategies for survival for their families and communities; however, very few youths are involved in agro co-operatives. With high youth unemployment, youth involvement is of paramount importance in forming enterprises to generate income. Agriculture is a promising venture, especially agro-processing, which will enable a lot of our unemployed youth to earn an income. Unemployment is indirectly linked to other social factors such as crime, and addressing unemployment will in turn have an effect on other social factors such as teenage pregnancy, et cetera:

\footnotetext{
'... people think that farmers are men and old people; however, I am a female and am young yet I am into farming ... because they are no jobs anymore and we have to find other ways to support our families.' (Participant 1,Focus Group Discussion, 36 year old female, 2020)

'... but Jabu is an exception, yes there are many women in our municipality who are in to cottage farming or small holder farmers; however, as you can see we are mostly old here and this should tell you that young people don't want to start business especially farming.' (Participant 5 Focus Group Discussion1, 65 year old male, 2020)
}

\section{Discussion}

The research has highlighted some of the challenges faced by cottage farmers in the Raymond Mhlaba municipality. Participants highlight the diverse types of farming they are involved in, stressing that they have a passion for it, although others do it as a survival strategy because of the scarcity of employment in their small towns. Pawlak and Kołodziejczak (2020) affirm that agriculture sector has a great potential to enable the desperately poor to survive, alleviate poverty, create employment and contribute to economic growth. However, there is a need to assist these farmers as they face numerous challenges in trying to grow their cliental and financial support from government and non-governmental organisations. The major challenges are accessibility of resources such as government departments and other organisations that could be of help to them; this is because they are located in rural areas far from big towns. Their road and transport infrastructure is poor, making it hard to access big towns such as King William's town, which is located $65-75 \mathrm{~km}$ away from Alice and Fort Beaufort and even further for areas such as Adelaide. This challenge also affects their marketing strategies and transportation of their goods. One of the participants (Nonzame) asserts that when their products are ready they join forces as women to go to town to sell their maize; however, she highlights that this task is difficult as they rely on public transport and they have to travel long distance.

This, therefore calls for a need for a revitalisation of rural areas, and Buheji (2018) and Buheji and Ahmed (2019) demand for a process that seeks to reverse rural decline, to develop a more resilient, sustainable and diversified local economy and to enhance the quality of rural communities, which is essential for rural areas.

Buheji and Ahmed (2019) further argued that the focus should be on creation and stimulation of opportunities that will generate income whilst preserving and enhancing the unique dynamics and features that make life special. According to them, this will ensure stability and increase local rural population by retaining and attracting young people. Moreover diversifying the economic and employment base, maintaining an acceptable participation and community pride. The issue of urban migration and urban poverty becomes a challenge for rural areas as most of the young people move to urban areas seeking greener pastures, living the elderly and the young in the rural areas. This is evident when one looks at the age groups of the participants in the study, most of whom are in their late forties. Rural development is therefore of paramount importance as a tool to curb urban migration and convince young people to stay and develop their rural areas. This is to be achieved through creation of jobs and provision of 'service delivery', for development to be directed to rural areas. Urban areas around South Africa are congested and saturated. The dreams of the youth who migrate to the cities are stunted as there is no more room or jobs for them. This leads to the homeless people whose numbers are increasing daily in our cities.

Survival of the fittest becomes a norm, which is a major contributor to the increase in crime rate that is high in the urban areas. Meyer (2014) asserted that local government and LED should play a vital role in rural development through infrastructure development, policy formulation, integration, 
support for small enterprise, creation of positive economic climate, facilitation of projects, formulation of strategies and provision of information. The main question one has to ask is if agriculture is of paramount importance and if we believe that it is the main tool for poverty alleviation in rural areas, what are the efforts of interventions on implementation? Programmes such as LED were founded to address the inequalities, yet we witness very little progress is achieved. The study also found that the issue of education is a problem as most elderly rural people are uneducated, yet they wish to learn more. This therefore calls for a different approach in addressing rural communities. The need to infuse the old with the new is essential, which is finding common ground to infuse indigenous knowledge with modern techniques of farming in ensuring a progressive tool for the growth and development of rural communities. It is clear that a lot of things need to be achieved in the Raymond Mhlaba municipality to support, educate and grow small cottage industries to ensure economic development in rural areas.

\section{Recommendation}

In order to alleviate poverty, new strategies, frameworks and policies that will reduce poverty in all dimensions and enhance security for South African rural areas are mostly based on agricultural or farming activities. This calls for a need to look at ways of using farming as a tool to develop and create employment in rural areas and focus on enhancing rural agroprocessing industries. This can be accomplished by empowering rural cottage industries by enabling community organisations and people to achieve sustainable livelihoods and authorise projects of the vulnerable and marginalised groups such as women, youth, people living with disabilities, etc., establishing networks of community-based learning centres and providing investment, training and mentorship for these small cottage industries. Importantly, education or knowledge is needed to assist and train these small cottage industries.

\section{Conclusion}

In conclusion, in terms of agro-processing for rural development, a lot of things need to be achieved by the government together with the small-scale farmers. The study has reviewed that small-scale farmers lack the knowledge and innovative farming methods. The small-scale farmers have little knowledge and understanding on agro-processing and poverty alleviation strategies. As a result effective support programmes such as agro-processing trainings and workshops, marketing strategies and funding processes should be pursued for an enhanced development of smallscale farming in the Raymond Mhlaba community. Local economic development should not just be a term; however, its work needs to be visible in the communities where we aim to make an impact. Strategies should be implemented targeting the vulnerable group that is the women, youths, people living with disabilities, the old, etc. The youth are not much involved in agriculture in Raymond Mhlaba, and hence efforts are therefore necessary to lure the youth into agriculture by providing them with land rights, training and funding.

\section{Acknowledgements}

The authors would like to acknowledge the community of Raymond Mhlaba for participating in this study. They would also like to acknowledge the assistance of the human settlements department that helped with data collection.

\section{Competing interests}

The authors have declared that no competing interests exist.

\section{Authors' contributions}

All authors contributed equally to this work.

\section{Funding information}

This research received no specific grant from any funding agency in the public, commercial or not-for-profit sectors.

\section{Data availability}

Data sharing is not applicable to this article as no new data were created or analysed in this study.

\section{Disclaimer}

The views and opinions expressed in this article are those of the authors and do not necessarily reflect the official policy or position of any affiliated agency of the authors.

\section{References}

Babbie, E., 2010, The practice of social research, Wadsworth Cengage Learning, London.

Babbie, E. \& Mouton, J., 2001, The practice of social research: South African edition, Oxford University Press Southern Africa, Cape Town.

Buheji, M., 2018, Re-inventing our lives: A handbook for socio-economic 'problemsolving', AuthorHouse, Bloomington, IN.

Buheji, M. \& Ahmed, D., 2019, The intent: Shaping the future of 'poverty economy', AuthorHouse, Bloomington, IN.

Business Link, 2019, Agreement to generate millions for rural Eastern Cape farmers, viewed 01 April 2021, from https://businesslink.co.za/agreement-to-generatemillions-for-rural-eastern-cape-farmers/business/.

Creswell, J., 2013, Research design: Qualitative, quantitative, and mixed methods approaches, 4th edn., Sage, Los Angeles, CA.

Degu, A.A., 2019, 'The causal linkage between agriculture, industry and service sectors in Ethiopian economy', American Journal of Theoretical and Applied Business 5(3), 59-76. https://doi.org/10.11648/j.ajtab.20190503.13

De Vos, A.S. \& Strydom, H., 1998, Research at grass roots: A primer for the caring professions, Van Schaik Publishers, Pretoria.

De Vos, A.S., Strydom, H., Fouché, C.B. \& Delport, C.S.L., 2012. Research at grass roots for the social sciences and human services professions, 4th edn., Van Schaik, Pretoria.

Department of International Development (DFID), 1999, Growth and poverty reduction: The role of agriculture, DFID Policy Paper, DFID, London.

Ellis, R., 1999, Learning a second language through interaction, John Benjamins Publishing, Amsterdam.

Hermann, M., 2009, 'The impact of the European novel food regulation on trade and food innovation based on traditional plant foods from developing countries', Food Policy 34(6), 499-507. https://doi.org/10.1016/j.foodpol.2009.08.005

Huttunen, S., 2019, 'Revisiting agricultural modernisation: Interconnected farming practices driving rural development at the farm level', Journal of Rural Studies 71, 36-45. https://doi.org/10.1016/j.jrurstud.2019.09.004

Iortyom, E.T., Sonwabo, P.M. \& Nel, W., 2018, 'Analysis of the economic impact of Rural Enterprise Development Hub Project on maize farmers in Mqanduli, South Africa', Indian Journal of Agricultural Research 52(3), 243-249. https://doi. org/10.18805/IJARe.A-319

Kapur, R., 2019, 'Significance of rural development', Acta Scientific Agriculture 3(7), 167-173. 
Karnani, A., 2017, 'Marketing and poverty alleviation: The perspective of the poor', Markets, Globalization \& Development Review 2(1), 1-18. https://doi. org/10.23860/MGDR-2017-02-01-05

Krefting, L., 1991, 'Rigor in qualitative research: The assessment of trustworthiness', American Journal of Occupational Therapy 45(3), 214-222.

Meyer, D.F., 2014, 'Local economic development (LED), challenges and solutions: The case of the northern Free State region, South Africa', Mediterranean Journal of Social Sciences 5(16), 624

Modrego, F. \& Cazzuffi, C., 2015, Desigualdad y crecimiento económico: Contribuciones desde el desarrollo territorial, viewed n.d., from https://www.rimisp.org/wpcontent/files_mf/1434663450155CCazzuffi2015_04_24_Desigualdadycrecimiento vfinal editado.pdf.

Organisation for Economic Cooperation and Development (OECD), 2006, The SME financing gap - volume 1: Theory and evidence, OECD, Paris.

Pawlak, K. \& Kołodziejczak, M., 2020, 'The role of agriculture in ensuring food security in developing countries: Considerations in the context of the problem of sustainable food production', Sustainability 12(13), a5488.

Rein, M. \& Schön, D., 1996, 'Frame critical policy analysis and frame reflective policy practice', Knowledge and Policy 9(1), 85-104.
Rogerson, C.M., 2009, Strategic review of local economic development in South Africa, Final report submitted to Minister S Shiceka of Department of Development Planning and Local Government (DPLG), Department of Development Planning and Local Government (DPLG) and German Agency for Technical Cooperation (GTZ), Bonn.

Siddiqui, K., 2015, 'Agrarian crisis and transformation in India', Journal of Economics and Political Economy 2(1), 3-22.

Statistics South Africa (Stats SA), 2016, Community survey, viewed 12 January 2020, from http://cs2016.statssa.gov.za.

The Nkonkobe Municipality, 2016, Integrated development plan: 2015-2016, The Nkonkobe Municipality, Alice.

United Nations (UN), 2014, World urbanization prospects: The 2014 revision, viewed n.d., from https://population.un.org/wup/publications/files/wup2014-report.pdf.

Walelign, S.Z., Pouliot, M., Larsen, H.O. \& Smith-Hall, C., 2017, 'Combining household income and asset data to identify livelihood strategies and their dynamics', The Journal of Development Studies 53(6), 769-787. https://doi.org/10.1080/002203 88.2016.1199856

World Bank, 2001, Poverty manual, World Bank Institute, Washington, DC.

Yunus, M., 1998, 'Poverty alleviation: Is economics any help? Lessons from the Grameen Bank experience', Journal of International Affairs 52(1), 47-65. 